1

\title{
Melancholia as a Sense of Loss: An Introduction
}

\author{
Martin Middeke and Christina Wald
}

'Why is it that all men who have become outstanding in philosophy, statesmanship, poetry or the arts are melancholic?' This statement, which had been ascribed to Aristotle for a long time, can be regarded as the foúndation of the long-standing cultural history of melancholia. ${ }^{1}$ It shows that the phenomenon was regarded as more than an illness already in ancient times. In $350 \mathrm{BC}$, melancholia is understood as an epiphenomenon of, or even as a prerequisite for, outstanding cultural and political achievements and deep philosophical insight, although Pseudo-Aristotle at the same time acknowledges the pain caused by melancholia. In its interrelated medical and cultural histories, melancholia has maintained such a complex denotation: it has frequently been understood as a painful condition which opens up an avenue to deeper insight, to judiciousness and to creativity. Such a 'nobilitation' constitutes the main difference between melancholia and today's category of depression. Despite the fact that traces of melancholia's history can be found in the current psychiatric definition of depression, the cultural status of the phenomena differ decisively. ${ }^{2}$ The 'nobilitation' of melancholia and its association with philosophy, science and art is emblematically captured in Albrecht Dürer's engraving Melencolia I, an image with an immense iconographic influence on later visual representations of melancholia (Fig. 1.1), including Alberto Giacometti's cube that is reproduced on the cover of this book. Here, as elsewhere in the visual arts, the representation of the melancholic makes a psychological state of mind correspond with the outside world; the personification of melancholia is situated in allegorical or symbolic spaces.

When studying the history of melancholia from ancient times to today, one is dazzled by the chameleonic changes of melancholia, whose definitions vary decisively in different epochs and cultural contexts. Many epochs have been described as particularly prone to melancholia, including our present day - a diagnosis which concerns literature and the arts as well as literary and cultural theory. Andrew Gibson, for instance, sees the 'contemporary aesthetic realm... [as] a melancholy space' (136), Juliana Schiesari 


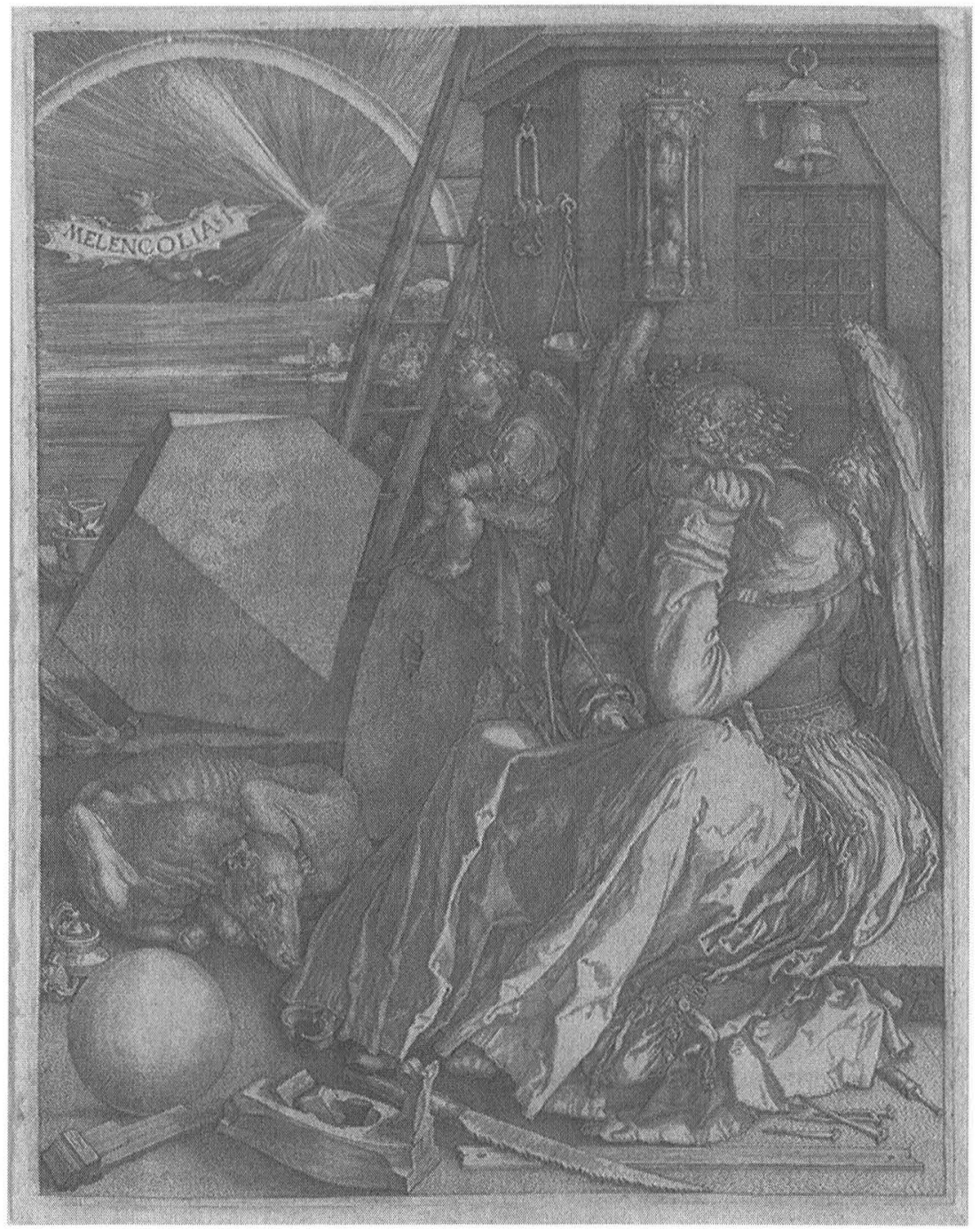

Figure 1.1 Albrecht Dürer, Melencolia I (1514); Staatliche Graphische Sammlung München

detects a 'rhetoric of loss' (1) in contemporary cultural theory, and Naomi Schor even diagnoses a general 'melancholy of the disciplines' (1). Our collection aims at reassessing the productivity of melancholia as a critical category of analysis and at addressing crucial aspects of melancholia from early modern times to the present day in British literature and culture, including its expansion (and contestation) by colonization. Since the 
theoretical and cultural implications of melancholia are more far-reaching, however, and since all contributors to this volume have adopted an interdisciplinary approach, we hope that scholars from fields other than English literary and cultural studies might also find the ideas brought forward in this volume enriching as well as applicable and pertinent to their research.

Our collection sets out to trace melancholia's versatile history since the early modern period, a time in which arguably many important social, political, religious, economic and scientific developments that characterize our present world began. One central thread woven into the contributions of this volume, therefore, is the relationship between melancholia and modernity - understood in its broader sense of delineating a (post-) Renaissance and (post-)Enlightenment world characterized by such ensuing phenomena as secularization, the rise of human reason and the sciences, the onset of capitalism, industrialization and globalization. We have based our work in this volume on the thought that the multifaceted phenomenon of melancholia can best be approached with a diachronic approach and a multiperspective methodology. Therefore, the essays in this collection are presented in a loose chronological order that allows for a diachronic reading, but they do not offer a linear and exhaustive study of melancholia's history. ${ }^{3}$ Instead, they highlight selected moments in this history, moments which seemed particularly productive to us, by focusing on representative literary and cultural texts, and they employ various theoretical approaches to the selected material.

As the central thesis regarding a common denominator of the heterogeneous concepts of melancholia and, especially, concerning its status in literature, culture and theory, we would argue that melancholia always emanates from (or, in some cases, is accompanied by) a sense of loss. This sense of loss, to name but a few instances, might be a response to a sense of absence or lack, a deep-rooted, often unaccountable craving or a yearning for something more, different or other; a sense of absence that is often explained as a story of a previous loss - most famously, the loss of the Golden Age and the eviction from Eden. No matter whether it relates to religion or philosophy, medicine or psychology, literature or the visual arts, this sense of loss may surface as a sense of nostalgia for a better cultural or individual past; a loss of balance, visible in a surplus of black bile, as diagnosed by the ancient theory of the Four Temperaments propagated most famously by Hippocrates and Galen; a loss of interest in the outer world, as described by Renaissance humanists such as Ficino and Burton; the loss of a beloved object or even the ability to love; a loss of self-esteem or of self-respect resulting in self-reproach or in the conviction of being irremediably guilty, as Sigmund Freud has characterized melancholia in his early work on 'Mourning and Melancholia'. As eminent literary figures such as Hamlet demonstrate, these discourses of melancholic loss often intersect and culminate in art; Hamlet loses not only his father but also his trust in justice 
and honesty, his ability to love his mother and Ophelia, his self-esteem in the face of his inability to take revenge, and so much of his 'mirth', his lust for life, that he flirts with suicide - but, at the same time, he is, of course, credited with deep philosophic insight. The fact that Shakespeare drew on early modern medical discourses of scholarly melancholia, love melancholia as well as melancholic madness, and that Freud in turn in his groundbreaking work on mourning and melancholia referred to Hamlet is one of many examples that demonstrate the synchronic and diachronic cross-fertilization of medical and artistic discourses on melancholia.

Of many possible aspects, two seminal manifestations of this melancholic sense of loss need some special introductory remarks as they have been particularly influential in the history of melancholia: (1) the anticipation of the loss of one's own life and a resulting sense of temporal difference, that is, the sense of a loss of time; and (2) the loss of an object and the consequences which this loss has on the subject. These two phenomena pervade the history and phenomenology of melancholia through all times, but had their heydays in particular epochs. While the thought of vanitas, for instance, has been a perennial human craving, the first notion of time and temporality has been of particular importance for philosophy and literature since Romanticism. The second notion has become more central ever since Freud's work on melancholia, which offered a productive and innovative approach to melancholia not only to psychology but also to cultural theory.

First, melancholia describes a specific sensibility for the break between an individual's life and its death, the anxious consciousness of which is fostered by the knowledge of the temporal aspect of a limited lifespan. This existential rupture and blankness produced by temporal difference underlies the epistemological void between subject and object in each act of knowledge and recognition. Independent of the individual, cultural or historical context in which melancholia appears, any idea of 'loss' always involves a temporal dimension. Thus, by analysing the discourse of melancholia and especially the correlation between the melancholic state of mind, human experience of time and temporality and their aesthetic reflection in art and literature, fundamental anthropological insights into the existential human condition can be gained. From a psychological or psychoanalytical perspective, a melancholic experience of time and temporality unveils itself as a pathological sadness, a paralysing anxiety and, particularly, as an agonizing (if sometimes comforting) insistence on the past. We shall see this argument taken up and proved implicitly or explicitly by almost every article in this collection. The insistence on the past entails the loss of the future; it creates the impression, as it were, of a standstill of time. Such a deadlock situation involves the impossibility of forgetting, a confounding self-punishment and a tantalizing sense of guilt, which makes it impossible for the melancholic mind to live freely with and in time or to strive confidently for the future. In the melancholic mind, the temporal limits of human life, the temporality 
of human existence, and the very consciousness of it determine a precarious experience of the present moment. For Martin Heidegger, the existential, temporal movement in time entails both tranquillity and alienation, which makes Sein/Being (understood as the sum of criteria or conditions by which any specific entity can be) and Dasein (understood as that being that will give access to the question of the meaning of Being) entangle themselves. In other words, Dasein can only be that being for whom the question of Sein is important, the being for whom Sein matters. This, of course, is nothing but human existence itself that relates to (its) Being via interpretation, that is, via the interpretation that approaches the meaning of Being itself through an analysis of the temporality of its Dasein. While observing ensuing phenomena such as Angst and mortality, Heidegger speaks of the 'thrownness' and 'falling' of Dasein, from which results the existential structure of 'care' (see Heidegger, especially pt 1 , ch. 4, 'Care as the Being of Dasein' 225-74). '[The] 'movement' of Dasein in its own Being,' Heidegger notes, 'we call its "downward plunge" [Absturz]. Dasein plunges out of itself, into the groundlessness and nullity of ... everydayness' (223).

As something 'thrown' and 'fallen', Dasein (that is, our Being-there) can only self-actualize in the face of its temporality and because of its finiteness. Past, present and future hence form the three ecstasies of temporality: human beings live towards their future, the far end of which, inevitably, is death. To live, in Heideggerean understanding, hence always equals beingtowards-death. Everyday consciousness, common sense or an optimistic belief in human progress may refute or suppress this idea as a rather pessimistic view of the human condition, whereas art and literature have always been fascinated by such melancholic thoughts of memento mori or vanitas vanitatum et omnia vanitas, often iconographically captured in a scrutinizing gaze on the human skull; the pose in which Hamlet is most often depicted (Fig. 1.2). Or, to put it the other way around, it requires a melancholic consciousness to reflect upon and give expression to this particular sense of loss, that is, lost time and the anticipation of death. One may think of Jaques's (mediaeval) philosophy of the seven ages of man brought forward in Shakespeare's As You Like It or of Feste's pensive songs in Twelfth Night (especially 'O Mistress Mine', 'Come Away, Death', 'Hey Ho, the Wind and the Rain'), all of them melancholically recalling death that consistently casts a shadow on the fleeting moment of human passion; one may point to the melancholy consciousness of temporality in Romanticism and the attempt to heal or at least to soothe the wound of time via imagination; or one may recall the impression of a painful standstill of time, an incongruence between the observation of a world in the midst of ruthless flux and incommensurable acceleration and a subjective feeling of stagnation and deceleration - felt as ennui, boredom and agonizing, empty repetition, as famously theorized by Kierkegaard - as it is prevalent, for instance, in late nineteenth-century aestheticism. The melancholic mind no longer feels subjective (i.e. inner duration) and 'objective' manifestations of time 


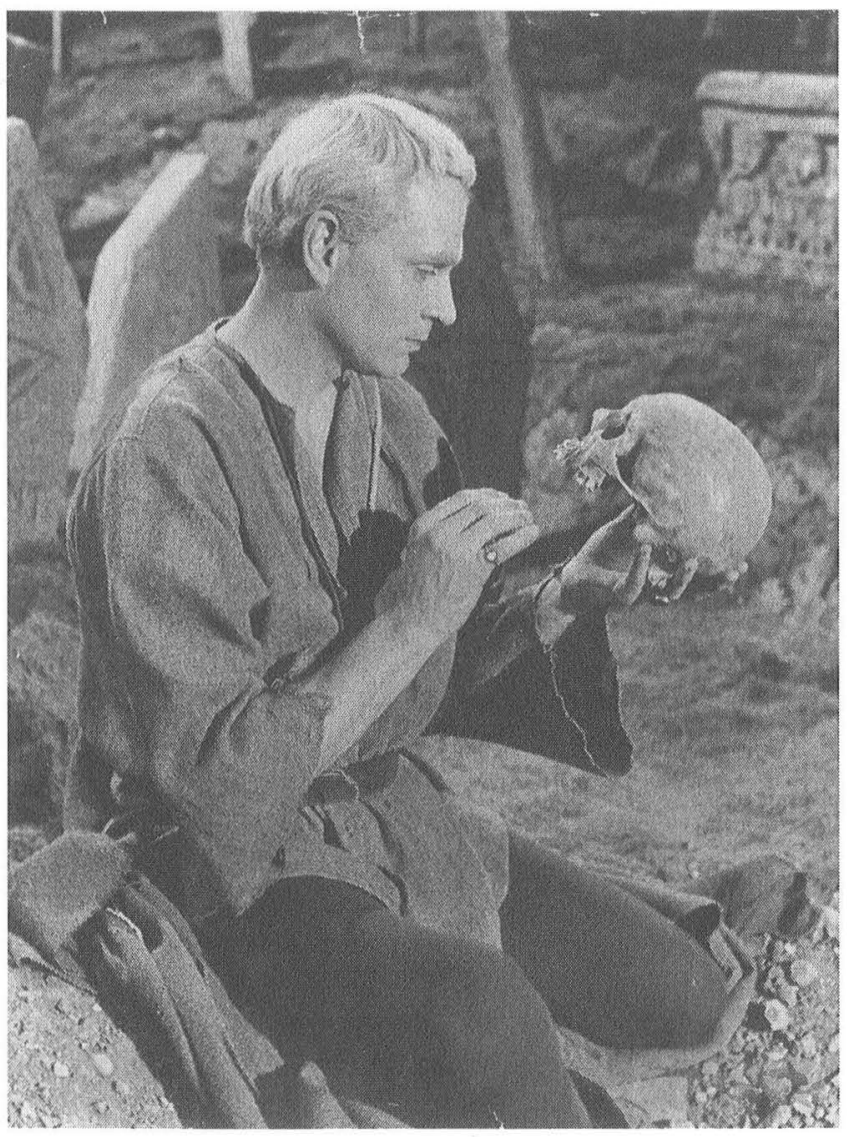

Figure 1.2 Laurence Olivier as Hamlet, scene shot from Hamlet (1948), British Film Institute/ITV Studios Global Entertainment

consciousness (i.e. clock time) as forming a meaningful continuum, but as disrupted and dysfunctional. ${ }^{4}$

The post-Darwinian collapse of ethical, moral and religious certainties has, for many, fostered an experience of reality devoid of order, causality and direction, and it is this impression of a meaningless reality (without God) that ineluctably puts forward the temporal dimension of human life (see Middeke). Time and temporality thus appear as opponents of human beings, who perceive themselves alienated, insignificant and transitory. Art and literature from the nineteenth to the twenty-first century become principal witnesses of this process of alienation and disenchantment, the psychological effect of which, on the one hand, is characterized by deepest melancholia. On the other hand, however, the incitement inherent in such 
a melancholic sensitiveness yields the highest aesthetic innovation and productivity, as manifold reflexes of this theme in art and literature - no matter if of realist/naturalist or of highly auto-reflexive, experimental provenance have abundantly shown until the present day. Artistic representations of such a melancholic displacement in literature are multifaceted and range from Hans Castorp's highly melancholic disengagement with the time of the flat country in Thomas Mann's Magic Mountain, Virginia Woolf's devastatingly shocking portrayal of the irreversibility of time in To the Lighthouse, Marcel Proust's concept of memory in Remembrance of Things Past, the merciless corroboration of empty repetition in Samuel Beckett's Waiting for Godot to postmodernist experiments with time and time-consciousness. What all these examples have in common is their preoccupation with temporality and human transitoriness and an insight into the impossibility of making up for the loss of time.

Second, the other strand of the complex, and sometimes contradictory," discursive history of melancholia, which we should like to discuss in some detail, has focused on the importance of loss for subject formation. This is the aspect which was highlighted and expanded by Freud in his work on melancholia. In his early article on 'Mourning and Melancholia', to which many of our contributors refer, Freud argues that the melancholic reaction to loss differs from mourning, although both share similar symptoms. He understands mourning as Trauerarbeit, as the working through of loss, which eventually results in the subject's ability to overcome the lost person, object or idea. By contrast, the melancholic refuses to acknowledge the loss and keeps the lost object psychically alive by introjecting it into the ego. As the feelings of the self for the lost person (or object or idea) have always been ambivalent, the self also introjects these contradictory feelings, which are now directed against the internalized object, that is, against a part of the self. Thereby, the self is divided; it observes and treats parts of itself as an object - or, the other way around, the internalized object judges the self critically. In his later work on the 'The Ego and the Id' (1923), Freud argues that the psychic instance of the Über-Ich, the super-ego, is created by such an introjection - this explains the heightened self-criticism that characterizes the melancholic and that distinguishes melancholia from mourning. It explains why '[i]n mourning it is the world which has become poor and empty; in melancholia it is the ego itself' ('Mourning and Melancholia' 246). The radical argument of Freud's later work is that a melancholic response to loss should not be seen as the pathological exception to the healthier, more common response of mourning but that melancholic responses to loss are so widespread that the ego itself must be understood as the result of early processes of melancholic identification. Freud famously posits that 'the character of the ego is a precipitate of abandoned object-cathexes and ... contains the history of those object-choices' ('The Ego and the Id' 29). Therefore, the subject contains the object within the ego but also as the ego. 
In the twentieth and twenty-first centuries, cultural theorists have adopted Freud's concept of melancholia to shed light on processes of individual identity formation, in particular with regard to gender, sexuality and ethnicity, but they have also adopted the concept to describe the refusal or the inability to mourn on more collective levels. After influential psychoanalytical feminist writings on melancholia, such as Luce Irigaray's Speculum de l'autre femme (1974) and Julia Kristeva's Soleil noir: Dépression et mélancholie (1987), melancholia since the 1990s has advanced to an important concept in poststructuralist gender and queer theory. Most prominently, Judith Butler has employed Freud's work to conceptualize the assumption and maintenance of gender identity in a heteronormative social framework as a melancholic activity. She argues that '[g]ender itself might be understood in part as the "acting out" of unresolved grief' (The Psychic Life 146) - an unresolved and disavowed grief for the loss of the same-sex parent as object of desire. Through a critique of Freud's notion of the Oedipus complex and his concept 'of melancholic identification, she develops a notion of gender (and of sex) as the result of psychic processes that stem from early losses, losses which are already governed by a taboo of homosexuality (that must precede, if one follows Freud's psychoanalytic logic, the incest taboo posited by him). The loss of the same-sex parent as an object of desire is disavowed, the lost object is introjected, and the gender identity of the self is thereby established. Yet, Butler in a next argumentative step conceptualizes not only the gendered psyche but also the sexed body as a product of melancholic incorporation. Thereby, Butler pleads for a radically new interpretation of 'melancholic anatomy' about four hundred years after Robert Burton's epoch-making The Anatomy of Melancholy. ${ }^{5}$ Her theory also offers an explanatory pattern to account for the difficulty to grieve publicly for the victims of AIDS and, more recently, in her books on Precarious Life: The Powers of Mourning and Violence (2006) and Frames of War: When Is Life Grievable? (2009), she has criticized the division of grievable and non-grievable lives along the lines of racial, religious and national belonging at times of war.

Butler's work demonstrates that the renewed interest in melancholia today is part of the ethical turn which does not emphasize the playful postmodern position of 'anything goes' but the commitment to political and ethical questions. It is such a politicization of melancholia that is at stake in postcolonial, gender and queer studies which have perceived 'melancholia at the turn of this century... [as] a crucial touchstone for social and subjective formations' (Eng and Kazanjian 23). As the development of Butler's writings illustrates, concomitant with the redeployment of melancholia for gender and queer studies, the category has become relevant for the cultural analysis of colonialism, postcolonialism and the establishment of ethnic or 'racialized' identities. Studies like Paul Gilroy's Postcolonial Melancholia (2005) and Anne Anlin Cheng's The Melancholy of Race (2000) have led to an extended awareness of melancholia, which not only shapes European cultural history 
but also plays a role in intercultural, global, colonial and postcolonial processes of dominance and exchange. In a similar manner to Butler, who posits that a 'national melancholia' stems from the disavowed mourning for the victims of the war waged by the USA against, for example, Iraq (Precarious Life xiv, 148), Gilroy has argued that repressed parts of England's colonial history find expression in melancholic symptoms within the present British society. According to Gilroy, Great Britain suffers from a 'postimperial melancholia' (90), because the '[r]epressed and buried knowledge of the cruelty and injustice that recur in diverse accounts of imperial administration can only be denied at a considerable moral and psychological cost' (94). In his contribution to our volume, Gilroy further investigates the 'closed circle' of Britain's postcolonial melancholia and calls for an alternative to this melancholic condition, namely, the conscious working through of the colonial past that might allow for a better future. Cheng employs the notion of melancholia to account for the effects of colonization, slavery and migration, choosing the example of contemporary African and Asian Americans. For Cheng, melancholia offers 'a particularly apt paradigm elucidating the activity and components of racialization' (10), because, on the one hand, the immigrant introjects the white ideal and, with it, a critical stance towards his or her non-white self. On the other hand, also '[d]ominant white identity in America operates melancholically' (11), as Cheng argues on the same trajectory as Gilroy and Butler, because the violations of democratic ideology (for example, the genocide of Native Americans or immigration discrimination) are often disavowed, and with them the very fact of racism. Cheng proposes that melancholia is 'a powerful critical tool' in this racist context, because it can help to account for 'the guilt and the denial of guilt, the blending of shame and omnipotence in the racist imaginary' (12) and to shed light on 'racial identity as a melancholic formation' (24). In conclusion, the complex territory outlined above provides abounding evidence of that multifaceted sense of loss that we purport to be underlying melancholic experience. The contributions to this volume all refer to the two fundamental senses of loss accentuated here, and they will differentiate them further according to the broad thematic, theoretical and historical spectrum of the melancholic chameleon.

We have divided the book into four main sections, which, in a loose chronological order, focus on particular thematic, theoretical and historical aspects of melancholia. The first four essays, grouped under the heading "The Melancholic Tradition, Creativity and Gender: Early Modern to Eighteenth Century', show how decisive melancholia was for establishing a literary position in the sixteenth, seventeenth and eighteenth centuries, when melancholia already had a long-standing cultural history that made 
it attractive but at the same time difficult for early modern authors to inscribe themselves into this tradition - in particular, as we shall see, for female authors. The next section is dedicated to the nineteenth century and its ambivalent stance towards progress and modernization, which created a particular form of melancholia. The third part investigates the relevance of melancholia to colonialism and postcolonialism, offering case studies from the nineteenth to the twenty-first centuries. The final four articles assess the current state of melancholia studies and explore the debatable relevance of melancholia for postmodernity.

The opening article of the first section, Tobias Döring's 'Yet Once More: Melancholia and Amnesia in Milton's Lycidas', draws on Freud's engagement with melancholia in 'On Transience' (1916) and his epoch-making 'Mourning and Melancholia' (1917) to understand not only individual reactions to loss but also 'the cultural career of melancholia'. Döring asks how Freud's insight into 'the scarcity value in time' can not only be applied to the loss which John Milton must have felt when a close friend died but also to the literary question which Milton faced when writing Lycidas, an elegy in memory of his deceased friend: 'how can a poet, and especially an elegist, align himself with a tradition such as pastoral and at the same time make it scarce, so as to make his version of it valuable?' (p. 25). In other words, how can a poet inscribe himself into a literary tradition of melancholia that is founded on a notion of exclusivity, when every claim to the melancholic position makes it inadvertently less exclusive? Döring suggests that Milton overcomes this aporia by writing an elegy not only on his friend but also on pastoral elegy itself. He thus emphasizes the importance of both memory (and indeed often obsessive memory) for melancholia and the importance of amnesia, of 'a clearing of the cultural field so as to clear the space for an inscription of the new' (p. 27).

The other contributions to our early modern section turn to the importance of sex, gender and sexuality for the study of melancholia. Ever since Pseudo-Aristotle's statement, melancholia has usually been understood as an inherently masculine phenomenon - as far as it was connoted positively. Therefore, melancholia is of interest for gender studies in two respects: first, as a historic phenomenon that grants insight into the differentiation and hierarchy of the sexes and, second, as outlined above, as an analytical category derived from psychoanalysis. While Butler is the chief representative of a theorizing of gendering through melancholia, Juliana Schiesari has contributed a seminal study to the complementary phenomenon, The Gendering of Melancholia: Feminism, Psychoanalysis, and the Symbolics of Loss in Renaissance Literature (1992). Anne-Julia Zwierlein and Gabriele Rippl draw on Schiesari's ground-breaking work for their explorations of gendered melancholia in both the English motherland and the colonies of the New World in the sixteenth and seventeenth centuries. In 'Male Pregnancies, Virgin Births, Monsters of the Mind: Early Modern Melancholia 
and (Cross-)Gendered Constructions of Creativity', Zwierlein shows how male writers appropriate the imagery of pregnancy and birth to represent their artistic work. As she elucidates with reference to the work of Philip Sidney, Edmund Spenser, William Shakespeare and John Milton, authors attempt to forge notions of masculine autogeny that is independent of female collaboration. Zwierlein ends her article with a consideration of female reappropriations of such melancholic self-fashionings, including the work of Margaret Cavendish. She thus introduces the central concern of Rippl's contribution on 'Mourning and Melancholia in England and Its Transatlantic Colonies: Examples of Seventeenth-Century Female Appropriations.' Focusing on the English aristocrat Margaret Cavendish, Duchess of Newcastle, and the New England Puritan Anne Bradstreet, Rippl explores how these women adopt the male-centred discourses of melancholia not only to express their feelings of loss but also to fashion themselves as creative authors. Rippl identifies decisive differences between them: Cavendish uses melancholia not only as a clinical term but also as an aesthetic concept to describe her overflowing fancy and her equally brimming style. Thereby, Cavendish fashions herself as a creative writer. By contrast, Bradstreet does not have equal access to elitist codes of melancholia. Instead, she uses the elegy form and thus, as Döring shows in his article, an inherently male and melancholic genre, to come to terms with her personal experiences of loss in the colonies. Doing so, Bradstreet displays and reflects on her intense mourning. However, as Rippl shows, Bradstreet's mourning should by no means turn into a melancholic form of desperation or philosophical doubt, because both would be deeply at odds with the religious beliefs of the Puritan who sees her New England life full of privations as God's plan that ought not to be questioned. Sabine Blackmore traces further the interests of Rippl and Zwierlein by investigating the poetry of Mary Leapor, whose reclamation of melancholia as a working-class female author is exceptional. In " To pictur'd Regions and imagin'd Worlds": Female Melancholic Writing and the Poems of Mary Leapor', Blackmore shows how Leapor establishes an innovative female aesthetics of melancholia by having her poet-speaker Mira appropriate a literary position in the male melancholic tradition - a position which acknowledges the esteemed pensiveness of melancholia as well as its darker side of desperation.

As part of its nobilitation, melancholia has been linked to discourses of genius throughout its history, but in particular in German and English Romanticism, a period to which our next section turns. Famously, John Keats's 'Ode on Melancholy' praises bitter-sweet melancholia as the 'wakeful anguish of the soul' (I. 10; our emphasis). For Keats's lyrical I, who recommends to 'glut thy sorrow' (1. 15), melancholia sits in 'the very temple of Delight' (1. 25) and provides a special sensibility that is only available for an elected few. Paying tribute to the 'sadness of her [that is, of melancholy's] might' (1. 29) in his ode, he at the same time demonstrates the 
poetic 'might of sadness'. In 2006, the exhibition 'Melancholia: Genius and Madness in Art', shown both in Berlin's New National Gallery and Paris's Centre Pompidou, took up the association of insanity and genius and traced it from Dürer's engraving to contemporary art; the success of the exhibition with visitors demonstrated forcefully that an interest in the intersection of melancholia, genius and insanity prevails in the twenty-first century, even though the concept of the 'genius' needs to be, and indeed has been, criticized.

Andrew Gibson and Felix Sprang look at the dark undercurrent of melancholia and the male melancholic genius in the nineteenth century. As Sprang proposes in " "The dark bottomless Abyss, that lies under our feet, had yawned open": The Recision of the Male Melancholic Genius in Carlyle's Sartor Resartus', Carlyle's Sartor Resartus satirizes two stock melancholic types of Romanticism: the adolescent melancholic Weltschmerz and the melancholic experience of love melancholia, of intense, but unrequited love. Romantic images like the lonely wanderer so powerfully represented in the paintings of Caspar David Friedrich are exposed as dead metaphors or even kitsch in Carlyle's narrative. Being able neither to communicate with nature and derive consolation from it nor to derive meaning from history, Carlyle's work accepts the melancholic insight into the transience and contingency of life; it acknowledges the empty void without seeking solace. Thus, Sprang concludes, Sartor Resartus 'marks the end of a naïve Romantic conception of the creative, usually male melancholic genius' (p. 98). By contrast, Tennyson's early poetry rejects such an acceptance of contingency, as Gibson shows. Citing Tennyson's 'They came, they cut away my tallest pines' in his title, Gibson looks at the melancholic impact of modernity, arguing for a Benjaminian sense of 'catastrophe in permanence', of a sense of modernization as ruination, which differs decisively from the melancholia represented by Dürer's engraving. The modern notion of melancholia entails a sense of circularity, of an unbreakable pattern of repetition, but it nonetheless constitutes a form of refusal, 'of articulating a chronic and persistent disaffection from the way things seem immitigably to be' (p. 104). Gibson shows how both aspects of melancholia are central to Tennyson's early poems, which in a melancholic double-bind 'gesture towards a value that is radically heterogeneous to or incompatible with modernity but, like Agamben's limit figures, is also radically averse to full realization' (p. 110) - and this unattainability in turn leads to an intensification of melancholia.

The lack of consolation by history which both Sprang and Gibson highlight is also at stake in Peter Fritzsche's contribution on 'The Melancholy of History: The French Revolution and European Historiography'. Opening up British history to a European perspective, Fritzsche shows that the French Revolution had a deep impact on European consciousness, since it was perceived as something completely new, as something 'out of nature', as 
Edmund Burke put it. Such a sense of rupture at the same time led to a yearning for a past which seemed radically cut off from the present rather than as its extension. Feeling 'stranded in the revolutionary present', a 'sense of loss pooled in the folds of everyday life', and therefore, as Fritzsche argues, people sought consolation from remnants of the past such as ruins, while at the same time acknowledging 'the melancholy of history; its accounts will always remain incomplete and provisional' (p. 121). Attempts to commemorate the past via ruins were deeply connected to anti-imperial (that is, anti-Napoleonic) desires of preserving a national history, as Fritzsche shows. By arguing that in England, 'the scenes of the vanishing countryside quickly embodied the very essence of Englishness' (p. 124), Fritzsche offers the starting point for the analysis of Christoph Ehland and Stephan Kohl, whose contribution again demonstrates that this volume understands 'the literature of melancholia' in a broad sense which includes cultural texts. In their article 'Commercializing Melancholy: The National Trust', Ehland and Kohl look at the history of the National Trust since its foundation in the late nineteenth century. Understanding nostalgia as an attempt at repetition which simultaneously is aware of the inauthenticity of all repetition, Ehland and Kohl show how the initial project of setting nostalgic dreams of an idealized 'Old England' against the industrialized present has developed into a new' concept. Today, the National Trust offers 'commercially run profit centres' that resemble amusement parks rather than sites of museal nostalgia. Kohl and Ehland conclude that such a shift ought not to cause renewed nostalgia for the 'old National Trust', but instead should be regarded as a 'healthier form of everyday escapism' which is ideologically less problematic.

As the contributions to our section on 'Melancholia and (Post-) Colonialism' show, a desire for a pre-industrialized world was often projected onto the colonies, which were frequently understood 'as the very incarnation of the absence of history' (p. 126), as Peter Fritzsche puts it in his contribution. The essays in this part re-examine the relevance of melancholia for colonial and postcolonial texts and contexts that range from nineteenthcentury Australia, the South Pacific, and the Congo to present-day Britain many more examples could, of course, be added. In Kirsten Sandrock's assessment of 'the strange case' of Robert Louis Stevenson's South Pacific writings, she identifies a complex attitude towards imperialist discourse, which she describes as a form of 'pre-colonial melancholia', as a 'longing for a preindustrialized past that goes beyond the state of nostalgia, both in its degree of wistfulness and sense of morbidity as well as in its use of longing as source of creativity' (p. 148). Stevenson's ambivalent stance between empathy, narcissism and imperialism comes to the fore in his simultaneous romanticization of the colonial Other and his identifications with the colonized victims of Empire. In 'The Secret of the Father in the Colonial Secret: Rosa Praed's "Weird Melancholy"', Jennifer Rutherford turns to the colonial Australia of the nineteenth century, focusing on Rosa Praed's memoir My Australian 
Girlhood (1902). Rutherford calls for a new assessment of Praed's position, which many critics have understood, following Praed's self-fashioning, as progressively anti-racist and as feminist. She excavates the traumatic underpinnings of Praed's narrative and, drawing on the work of Maria Torok and Nicolas Abraham, Rutherford suggests that 'encryption' is a more adequate term than 'repression' to describe Praed's narrative strategies: Praed's memoir and in particular her account of the retaliations following the Hornet Bank Massacre of 1857 not only cover up the father's role as perpetrator but also encrypt the father as her secret love, as a lost narcissistic ideal.

Anne Enderwitz's contribution on 'Modernist Melancholia and Time: The Synchronicity of the Non-Synchronic in Freud, Tylor and Conrad' focuses on the fascination with the synchronicity of the non-synchronic, which comes to the fore, for example, when the narrator of Joseph Conrad's Heart of Darkness (1899) compares the culture which the European colonizers encountered in nineteenth-century Congo to the pre-civilized inhabitants of the British Isles once encountered by the Roman occupiers. Enderwitz outlines that, where Freud insists on the layering of lost objects from different times in the ego that is created and further formed by melancholic identifications, Conrad's novella enacts a melancholic narrative that seeks to restore the past in the present by postulating the co-existence of different stages of development. As such, evolutionary theory as developed by E. B. Tylor constitutes a point of convergence for both writers, since it postulates the synchronous existence of objects and beliefs from different time periods.

In his contribution to this volume, Paul Gilroy offers further thoughts on his influential concept of postcolonial melancholia. "The Closed Circle of Britain's Postcolonial Melancholia' traces the construction of the British as a 'vulnerable, wounded and unjustly treated people' (p. 188) in the Thatcher years, which in effect divested the victims of racialized hatred of their position as victims. Gilroy also shows how, not only in Enoch Powell's rhetoric but also until the present day, the just war against Nazi fascism (and its reactivation in soccer matches) blanks out any engagement with the history of British colonization and decolonization. Gilroy finds a more progressive stance in the novels of Jonathan Coe, which help to undercut post-imperial melancholia by satire and laughter. He closes his article with a hope for an overcoming of such melancholic denial: 'Somewhere, against the odds and in opposition to the logic of our national ailment, many people do want to mourn. At least half of the country is desperate to move on and work through the past' (p. 197).

At the heart of our final section on 'Postmodernism and PostMelancholia?' are contemporary engagements with melancholia which raise the question whether postmodernism - and its celebration of difference and loss - has led to an overcoming of melancholia or whether the concept still holds explanatory power today. The relation between melancholia and postmodernism is much disputed: is a postmodern relishing in difference 
and playfulness tantamount to an end of (modernist) melancholia or is the present 'popularity' of melancholia an indicator for the return of emotion and, quite literally, postmodernism upon the wane? Or has the postmodern present, as Gilroy's article suggests, not freed itself, is it characterized by a melancholic response to its past? Schiesari has argued that 'the melancholic sense of ineffable loss is only the flip side of the modernist espousal of progress, its objective or even chronological correlative: the self-critical tedium that comes after the euphoria of modernism, namely postmodernism' (3) - or, indeed, as Gibson's contribution shows, always happens concomitantly with modernization and might result, as Ehland and Kohl demonstrate, in nostalgia for a purer past. The modern utopia of perfection has failed, Ludger Heidbrink has argued in a similar vein, and led to contemporary indifference and lack of orientation. The dissolution of grand récits are a cause for the particular melancholic mood of the present, which can be observed in large parts of contemporary art, culture, society and politics, according to Heidbrink (Entzauberte Zeit; cf. also Melancholie und Moderne). It seems as if the boundless postmodern play with signifiers and differences as well as the much-conjured collapse of meta-narratives, as famously proposed by J.-F. Lyotard, do not, after all, automatically mean that the (modern) melancholic state comes to an end. Jean Baudrillard has pointed out that the 'cool', digital universe of a globalized (media) world leaves us behind in a disoriented state of information overkill. For Baudrillard, individuality and subjectivity of the human being fall victim to the new melancholia of simulation, which resolves not only the ideals of man's self-determination - as they arose from Enlightenment - but also literally every reality itself into the mere surface of the non-authentic and hyperreal.

The contributions to this volume which address this complex interplay of (post)modernity and melancholia open a spectrum of aesthetic responses to loss. As Elizabeth Sakellaridou's article 'Working at the Seams: Howard Barker's Tragic Trauerspiel' shows, the melancholic consciousness that is at the heart of Barker's take on tragedy and the Trauerspiel, which he calls 'the theatre of catastrophe', aims at the sublimation of melancholia but not at agency. Barker's anti-realist drama that is indebted to allegory has, Sakellaridou argues, an underlying moralizing attitude, as in a mediaeval morality play or a Baroque Trauerspiel, while it is coming to terms with a specifically postmodernist experience of historical catastrophe, with a 'deeprooted, mournful obsession with the fate of European culture' (p. 211). Barker does therefore not, as his model Walter Benjamin, ultimately develop strategies to attain a post-melancholic state of agency but instead 'anchor[s] himself in the permanence of melancholia as socio-cultural pathology' (p. 219), as Sakellaridou concludes after surveying his oeuvre.

Juliana Schiesari's contribution takes postmodern ethical employments of the category of melancholia in a new direction. Drawing on Freud's notion 
of civilization as a process of loss and repression, she argues in 'Melancholia and Mourning Animals' that melancholia has become a symptom of an unacknowledged species loss, both in humans and animals, and that by the act of acknowledging the animal, 'we can begin an act of mourning that can lead us to creative frontiers that radically revise our relation to the Other' (p. 224). With reference to J. M. Coetzee's Disgrace and J. R. Ackerley's We Think the World of You, Schiesari demonstrates how literary texts, alongside posthumanist theory, can help to rethink animal studies and to deconstruct 'speciesism'.

Johan Geertsema's and Pieter Vermeulen's articles are in many respects the apt final contributions to our collection, since they raise a fundamental question, namely, how literature in general and the novel in particular can break 'the melancholic spell', how it can develop a reaction to loss which enables ethical agency. They look for an answer to this question, both on the level of content and regarding aesthetic implications, and they reach 'equally interesting conclusions. In his article 'Melancholic Consolation? J. M. Coetzee, Irony and the Aesthetics of the Sublime', Geertsema discusses how in Coetzee's novels, in particular in Slow Man, an aesthetic response to loss can circumvent becoming an anaesthetic of pain. In doing so, he explicitly distances Coetzee's position from the valorization of melancholia in recent theory, which too often results in deadlock. In contrast to Barker, Coetzee aims at a non-allegorical response to loss, as Geertsema argues: Slow Man invokes but ultimately ironizes the idea of a sublime melancholia, of an attachment to loss, absence and the insight into a gap between the self and the world. Reading Slow Man against the position of the character Elizabeth Costello, who is usually seen as an intrafictional representative of the author, Geertsema proceeds against the grain of Coetzee criticism which tends to see his work 'as marked by an insistence on absolute otherness, radical passivity, and infinitely demanding ethical responsibility' (p. 251). Instead of reading Coetzee's oeuvre as melancholically sublime, Geertsema calls for a reassessment of Coetzee 'as a writer of the ordinary after the extraordinary, who is concerned with the concrete ways in which to work though trauma, suffering, and injustice' (p. 251). In a similar vein, Vermeulen is interested in what he calls the 'post-melancholic aesthetics' of David Mitchell's and Tom McCarthy's novels. Like Geertsema, Vermeulen criticizes the recent trend in cultural theory to valorize melancholia as the adequate ethical response to loss, as a heroic refusal to let go of the lost object. Asking for the development of a post-melancholic concept of subjectivity, Vermeulen suggests that a particular form of the realist novel might be the appropriate genre to make it 'a vehicle for a productive and resolutely post-melancholic linkage of loss and identity' (p. 255). In order to develop a post-melancholic stance, Vermeulen argues, the novel can enhance its social realism, it can insist on the materiality of the world, rather than focus in a psychically realist manner on the traumatization of its protagonist, whose 
kernel is slowly unravelled. Alternatively, Vermeulen concludes, the utopian dimension inherent in the social realist novel can sustain its psychological realism and emphasize the connectedness of the individual, also across cultures, and thus undermine any melancholic sense of isolation, while at the same time replacing the linear narrative that traces the traumatic source by a proliferating network of stories without a discernible core. Saying this, however, does not mean that realism and melancholia are by definition mutually exclusive as, for example, the novels of Thomas Hardy have amply demonstrated.

Our collection aims at throwing a fresh light on the history and phenomenology of melancholia, with regard to its philosophic and thematic preoccupations as well as its formal-aesthetical consequences. It particularly intends to examine and highlight the interaction between the discourses of medicine, psychiatry, psychoanalysis, literature, art and philosophy in terms of a British cultural history and its non-British, global connections and effects through colonization, migration and knowledge transfer. On the one hand, literature and art become principal witnesses in this process of uprooting and estrangement, whose psychological sensitivities show the symptoms of deepest melancholia. On the other hand, it is exactly the motivating force of the melancholic feeling which brings forth the greatest aesthetic power of innovation and productivity as the examples brought forward by the sixteen essays in this volume reveal. The apotheosis of difference, the acceptance of the void in any process of linguistic or symbolic signification accentuated by postmodernism, could not fully do away with melancholia. The tensions and frictions, however, between the desire for liberation from all melancholic dejection in the face of the abyss of epistemological nothingness and death and a sublime insight gained from the very melancholic grieving have not lost any of their cultural efficacy; indeed, the very tensions and frictions have been more interesting to the artistic mind than more-or-less easy solutions to the problem of loss. Contemporary examples range from literature, the visual arts, 'emo' music and its cult of sadness and sensitivity, to a broad public interest in depression as a disease of our times. An inevitably paradoxical situation of the melancholic prevails, yet it still seems to be fertile ground and, in fact, will forever be fertile ground: melancholia stems from a sense of loss, and at the same time - and if only because of grief or pain - such pain confirms our very existence; all knowledge gained in theorizing melancholia may thus point to the nature of or show a way out of dejection, yet its enigmatic ways hold us captive in aporia, which itself provokes new interpretation and, hence, change. Studying, reflecting on and representing melancholia thus means both a diagnosis of crisis and an avenue to new shores. 


\section{Notes}

1. Aristotle $155,953 \mathrm{a}, 11.10-12$. There is widespread doubt whether Aristotle is the author of this passage; it is usually ascribed to Theophrast (Klibansky, Panofsky and Saxl 32; Wagner-Egelhaaf 19).

2. In the 2003 edition of the Diagnostic and Statistical Manual of Mental Disorders, 'depressive disorders' are differentiated into 'major depressive disorder', which consists of one or several 'major depressive episodes', 'dysthymic disorder' and 'depressive disorders not otherwise specified' (American Psychiatric Association 369-81). The classification still contains traces of the category of melancholia, as it mentions melancholic features as specifiers for a major depressive disorder. These specifiers apply to patients displaying 'a near-complete absence of the capacity for pleasure, not merely a diminution' (419).

3. For research that more ostensibly aims at a complete historical overview of melancholia, see the only diachronic monograph on the issue so far: Jennifer Radden's The Nature of Melancholy: From Aristotle to Kristeva, which offers a collection of primary texts on melancholia from antiquity to the twentieth century. For the aim of teaching the literature of melancholia, Radden's reader constitutes a helpful companion piece to our collection. From a medical perspective, Stanley W. Jackson's Melancholia and Depression: From Hippocratic Times to Modern Times offers an enlightening historical survey of concepts of melancholia.

4. For the connection between melancholia and time-consciousness see the concepts of phenomenological psychology brought forward, for instance, in: Erwin Straus, Geschehnis und Erlebnis; Viktor Emil von Gebsattel, Prolegomena einer medizinischen Anthropologie. Ausgewählte Aufsätze.

5. Butler's work offers a productive perspective on the contemporary literature of gender melancholia. See, for example, Wald for a reading of contemporary drama in the light of Butler's theory.

\section{Works cited}

Aristotle. 'Book XXX.' Problemata / Problems II. Books XXII-XXXVIII. Trans. W. S. Hett. Cambridge: Harvard University Press, 1965 [c.350 вC]. 154-81.

American Psychiatric Association. Diagnostic and Statistical Manual of Mental Disorders: DSM-IV-TR. 4th edn. Text Revision. Washington, D.C.: American Psychiatric Association, 2003.

Burton, Robert. The Anatomy of Melancholy. Ed. Holbrook Jackson. New York: New York Review Books, 2001.

Butler, Judith. Frames of War: When Is Life Grievable? London: Verso, 2009.

—. Precarious Life: The Powers of Mourning and Violence. London: Verso, 2006. . The Psychic Life of Power: Theories in Subjection. Stanford: Stanford University Press, 1997.

Cheng, Anne Anlin. The Melancholy of Race: Psychoanalysis, Assimilation, and Hidden Grief. Oxford: Oxford University Press, 2000.

- Eng; David L., and David Kazanjian. 'Introduction: Mourning Remains'. Loss: The Politics of Mourning. Eds David L. Eng and David Kazanjian. Berkeley: University of California Press, 2003. 1-25.

Freud, Sigmund. 'The Ego and the Id'. The Standard Edition of the Complete Psychological Works of Sigmund Freud. Trans. and ed. James Strachey. Vol. 19. London: Hogarth Press, 1961 [1923]. 12-66. 
- 'Mourning and Melancholia'. The Standard Edition of the Complete Psychological Works of Sigmund Freud. Trans. and ed. James Strachey. Vol. 14. London: Hogarth Press, 1961 [1917]. 243-58.

Gebsattel, Viktor Emil von. Prolegomena einer medizinischen Anthropologie. Ausgewählte Aufsätze. Berlin: Springer, 1984 [1954].

Gibson, Andrew. 'Oublier Baudrillard: Melancholy of the Year 2000.' New Formations 50 (2003): 123-41.

Gilroy, Paul. Postcolonial Melancholia. New York: Columbia University Press, 2005.

Heidbrink, Ludger, ed. Entzauberte Zeit: Der melancholische Geist der Moderne. Munich: Hanser, 1997.

—. Melancholie und Moderne: Zur Kritik der historischen Verzweiflung. Munich: Fink, 1994.

Heidegger, Martin. Being and Time. New York: Harper \& Row, 1962.

Irigaray, Luce. Speculum de l'autre fermme. Paris: Les Éditions de Minuit, 1974.

Jackson, Stanley W. Melancholia and Depression: From Hippocratic Times to Modern Times. New Haven: Yale University Press, 1986.

Keats, John. 'Ode on Melancholy'. The Poems of John Keats. Ed. Jack Stillinger. Cambridge: Harvard University Press, 1978. 374-5.

Klibansky, Raymond, Erwin Panofsky and Fritz Saxl. Saturn and Melancholy: Studies in the History of Natural Philosophy, Religion and Art. London: Thomas Nelson, 1964.

Kristeva, Julia. Soleil noir: Dépression et mélancholie. Paris: Gallimard, 1987.

Middeke, Martin. Die Kunst der gelebten Zeit: Zur Phänomenologie literarischer Subjektivität im englischen Roman des ausgehenden 19. Jahrhunderts. Text und Theorie 1. Würzburg: Königshausen und Neumann, 2004.

Radden, Jennifer. The Nature of Melancholy: From Aristotle to Kristeva. Oxford: Oxford University Press, 2000.

Schiesari, Juliana. The Gendering of Melancholia: Feminism, Psychoanalysis, and the Symbolics of Loss in Renaissance Literature. Ithaca: Cornell University Press, 1992.

Schor, Naomi. One Hundred Years of Melancholy. Oxford: Clarendon Press, 1996.

Straus, Erwin. Geschehnis und Erlebnis. Berlin: Springer, 1978 [1930].

Wagner-Egelhaaf, Martina. Die Melancholie der Literatur: Diskursgeschichte und Textkonfiguration. Stuttgart: Metzler, 1997.

Wald, Christina. Hysteria, Trauma and Melancholia: Performative Maladies in Contemporary Anglophone Drama. Basingstoke: Palgrave Macmillan, 2007. 